\title{
ICT, trade openness and economic growth in Tunisia: what is going wrong?
}

\author{
Mounir Dahmani ${ }^{1} \cdot$ Mohamed Mabrouki $^{1} \cdot$ Adel Ben Youssef $^{2}$
}

Received: 12 May 2021 / Accepted: 15 February 2022 / Published online: 2 March 2022

(C) The Author(s), under exclusive licence to Springer Science+Business Media, LLC, part of Springer Nature 2022

\begin{abstract}
In the age of digital globalization, information and communication technologies (ICT) and international trade seem to have become the engines of economic growth. In this study, we investigate the impacts on Tunisia's economic growth of using ICTs and greater trade openness. We employ a cross-section augmented autoregressive distributed lag (CS-ARDL) model and apply Dumitrescu and Hurlin Granger causality test to panel data for 14 economic sectors in the period 1995-2018. The empirical findings suggest that use of ICTs has a long-term relationship with value added and increased economic growth in Tunisia. In addition, trade openness and gross fixed capital formation (GFCF) have a positive and significant effect on economic growth. We also examine the relationships among these variables in the short and long run. The Dumitrescu and Hurlin test reveals four bidirectional and two unidirectional causal relationships between the variables.
\end{abstract}

Keywords ICT · Trade openness · Tunisia - Dynamic panel $\cdot$ CS-ARDL $~ \cdot$ Panel causality test

Adel Ben Youssef

adel.ben-youssef@univ-cotedazur.fr

Mounir Dahmani

mounir.dahmani@isaeg.u-gafsa.tn

Mohamed Mabrouki

mohamed.mabrouki@isaeg.u-gafsa.tn

1 University of Gafsa, Rue Houssine Ben Kaddour, Sidi Ahmed Zarroug, 2112 Gafsa, Tunisia

2 University of Côte d'Azur, GREDEG UMR 7321 du CNRS, 5 rue du 22ème BCA, 06300 Nice, France 


\section{Introduction}

Economic growth is important for achieving economic and social development which are major national objectives. How to achieve maximum levels of welfare and improve competitiveness and economic growth have been the topics of a large body of political and scientific research.

Analyzing economic growth and its determinants is important for all economies and especially less developed countries and is critical in times of economic crisis such as those triggered by the COVID-19 pandemic. In this context, we need to pay attention to the importance of efficiency to achieve growth, and the productivity of internal activities such as innovation and job creation which are fundamental for achieving competitive advantage to promote sectoral growth and market dominance.

In this context, we need to focus on the factors which influence value-added growth such as gross fixed capital formation (GFCF), trade openness and the use of information and communication technologies (ICTs) to understand the national economic reality and formulate strategies to enable future economic development.

The role of trade openness in stimulating economic development has been the topic of research since at least the 1950s (Huchet-Bourdon et al. 2018). Carnevali et al. (2020) highlight the work of economists such as Smith, Kalecki, Kaldor, Ricardo and Thirwall among others, which emphasizes that trade between the countries allows intensification of production levels and increased income. Similarly, Toader et al. (2018) highlight the importance of international trade, both export and import, to facilitate economic expansion.

Likewise, Zaman et al. (2021) consider that trade openness and GFCF are significant in terms of identifying the level of income derived from exports and the capital outflows related to imports. They evaluate national trade competitiveness at the international level.

The theoretical and empirical literature emphasizes the increasingly major role played by technological innovation particularly ICTs which are considered general purpose technologies (GPTs), for improving sectoral productivity and accelerating economic growth. Innovative ICTs are considered radical innovations. Their introduction as GPTs has brought several technological and organizational changes in a wide range of activities (Antonelli 2017). According to Mickoleit et al. (2009), the diffusion of ICT throughout the economy is providing opportunities for productivity improvements by firms, and public and social institutions and the development of new products and services which are boosting multifactor productivity.

This points to the importance of up-to-date knowledge on the effects of those factors that can lead to economic growth and development. The present work analyzes the impact of these factors in the context of the Tunisian economy based on three input Cobb-Douglas production functions, to understand Tunisian economic growth and the elasticities of its components.

This study makes at least two contributions to the specialized literature on the impacts of ICTs on economic growth. First, it extends it by decomposing 
new OECD input-output data to construct an ICT diffusion index and uses the dynamic common correlated effects modeling technique for panel data proposed initially by Chudik et al. (2016) and developed further by Ditzen (2018) to perform the sectoral analysis. Second, our use of cross-sectoral data in the context of Tunisia is quite rare. Section 2 introduces the theoretical framework and discusses the relevant literature. Section 3 presents the data and the analyzed variables and describes the empirical methodology. Section 4 presents the results and draws some conclusions.

\section{Theoretical framework}

The development of ICTs and the innovations they facilitate have increased economic performance. Schumpeter (1942) discusses different types of innovations and suggests that they may be new products, new combinations or new markets. One characteristic of ICT is the ability to generate interactions which improve productivity. Their synergistic effects can affect the whole knowledge-based economy and lead to the production of new knowledge and greater productivity. Their temporal and spatial characteristics enable the rapid diffusion of knowledge and innovation to the productive sector. Thus, heavy investment by the developed countries in ICTs especially in productive sectors, has favored the transition to a global knowledgebased economy (Fukuda 2020). ICTs are one of the determinants of current production, and are increasing efficiency and productivity in a range of different sectors. Thus, economic performance, overall competitiveness and economic development depend largely on availability, adoption and use of ICTs (Toader et al. 2018).

Some authors (Frank et al. 2019; Park 2018; Vu et al. 2020) compare the ICT revolution to the first industrial revolution and the changes triggered by electricity and steam power. The United Nations defines ICTs as GPTs which promote power systems (Bresnahan and Trajtenberg 1995). The wide-ranging effects of ICTs both economically and socially have led to the emergence of a new paradigm based on intensive use of information and knowledge. In today's economies, ICTs are affecting almost all economic sectors, opening new economic opportunities, enabling entrepreneurial initiatives, and generating innovation and knowledge spillovers (Taalbi 2019). They are also enabling complementary innovations, thereby generating economic growth (Czernich et al. 2011).

Other strands of work focus on the relationship between ICTs and economic growth from two different perspectives. One stream of work examines the relationship between ICTs and economic growth using exogenous growth models. The second stream examines this relationship based on endogenous growth theory. In both cases, technological change is important for economic growth (Fernandez-Portillo et al. 2020).

The results in the literature differ depending on the country or group of countries studied, the time periods considered and the methods applied. In addition, the determinants differ between developed and developing countries and in the former the impact of ICTs on economic development is more pronounced than in the latter. Due to lack of data for the developing countries, most studies focus developed regions. 
However, the empirical literature provides mixed results for the effects of ICTs on economic growth. Some studies find a significant positive impact of ICTs on economic growth (Njoh 2018; Adeleye and Eboagu 2019; Ben Lahouel et al. 2021; Jorgenson and Vu 2016; Kallal et al. 2021; Niebel 2018; Sassi and Goaied 2013; Haftu 2019; Jung and Lopez-Bazo 2020; Toader et al. 2018; Vu 2011; Vu et al. 2020; Samimi and Arab 2011), others find a negative relationship of ICTs on economic growth (Bertschek et al. 2013; Ejemeyovwi and Osabuohien 2020; Haller and Lyons 2015; Ishida 2015; Mayer et al. 2020; Thompson and Garbacz 2011). It should be noted also that the impact of ICTs on economic growth is not homogeneous across countries (Mayer et al. 2020). In particular, developing countries are at a competitive disadvantage which serves to increase the dominance of the developed countries in a global context. ICTs provide opportunities for the developed countries to open up to and attract new markets which provides them with a relative advantage. Developing countries are not only less competitive in the international market but also are threatened in their domestic markets. Therefore, use of ICTs can delay catch up by the developing countries and increase the gap between the developed and developing countries. ICT also can have negative impacts on the income distribution in developing countries; it is more difficult for low-income developing countries to acquire the equipment they need to benefit from ICTs due to the high cost of access compared with the developed and high-income countries.

In the Tunisian case, Ben Lahouel et al. (2021) investigated the effect of ICTs on economic growth during the period 1970-2018 using a smooth transition regression and found that ICT investments contributed to economic growth. However, Kallal et al. (2021) used a panel pooled mean group form of the autoregressive distributed lag model for the period 1997-2015 in Tunisia and found that ICT had a positive long-term effect on economic growth but a negative short-term effect. Similarly, Naanaa and Sellaouti (2017) investigated the effects of technological change on growth based on an analysis of technology spillovers and their channels of transmission in five Tunisian manufacturing sectors during the period 1970-2012. In addition to showing that manufacturing sectors benefit from foreign direct investment only after a certain ICT development threshold, the authors suggest also that Tunisia should strengthen its ICT infrastructure. The positive impact of ICTs on economic growth was highlighted also by Saidi et al. (2015) who analyze the relationship between the rate of growth of GDP and the index of ICT use for Tunisia during 1975-2008. Nevertheless, we lack a good understanding of the overall contribution of ICTs to sectoral value added in Tunisia, and most sectoral analyses are biased because they fail to count for cross-sectoral heterogeneity and cross-sectoral dependence.

Another factor that can affect national economic development is degree of trade openness. First, it allows local producers to benefit from better quality imported intermediate products when domestic production is absent or weak, and to exploit ideas triggered by imports of innovative products including ICTs. Second, trade openness increases competition which in turn works to increase productivity, efficiency and innovative capacity among domestic producers (Huchet-Bourdon et al. 2018). However, the applied literature on the relationship between trade openness and economic growth does not find such a strong positive relationship (Hamel 
Breghish and Neama Ali 2021; Musila and Yiheyis 2015; Trejos and Barboza 2015; Carnevali et al. 2020; Huchet-Bourdon et al. 2018; Idris et al. 2017; Toader et al. 2018; Zaman et al. 2021).

ICT developments are have effects also on global trade. The gradual digitalization of economic processes has led to a restructuring of economic activities and the idea of the digital economy. From this perspective, application of internet-based digital technologies to the production of and trade in goods and services has become important for the international economy. By reducing the costs incurred by buyers for obtaining information on sellers' prices and product offerings, ICTs are making markets more transparent. Toader et al. (2018) suggest that use of ICTs is influencing economic growth indirectly through greater trade openness.

\section{Methodology}

\subsection{Data and preliminary analysis}

The annual data for the period 1995-2018 were extracted from the 2021 edition of the OECD Input-Output tables. Our analysis includes 14 economic sectors based on the International Standard Industrial Classification (ISIC) Rev. 4 of economic activities.

Trade openness (TO) is measured as the sum of the sector's exports and imports of goods and services divided by the sector value added (VA). The ICT diffusion index (IDI) captures the degree of ICT diffusion across all economic sectors and determines the share of ICT in the VA of a particular sector. The IDI provides policymakers with a simple and easy-to-use tool to assess diffusion of ICTs and better understand the specific challenges associated with their deployment to inform economic development strategies appropriate for that domain. Technically, the IDI is based on an input-output analysis (Leontief 1986) to assess sectoral economic performance and the interdependence between production and consumption in a specific economy (Mustafin and Kantarbayeva 2018; Suh and Lee 2017). In this latter approach, there is close interaction among the industries in an economy which produce a single type of commodity (output) and consume the goods or services produced by other industries (intermediate inputs) to achieve that output. As reported by Miller and Blair (2009), the rows in the input-output table present the total intermediate supply values for each sector and represent the horizontal demand side of the Leontief model. The goods and services produced may be consumed by other sectors as intermediate products or consumed by households or government as final products. The columns in the table present the supply side and describe the composition of the inputs required by a particular industry to produce its output.

Similar to the approach based on the demand-side model in Suh and Lee (2017), IDI is calculated by dividing the intermediate input of ICTs to sector $j$ by the total input of sector $i$, as follows: 


$$
I D I=\left(\frac{x_{i j}}{x_{i \bullet}}\right),
$$

where $i$ and $j=14$ productive sectors.

The ICT sector is defined by the OECD (2009) as combining "all economic activities that contribute to the visualization, processing, storage and transmission of information electronically" and is classified according to the ISIC Rev.4 (United Nations 2008). It includes several industries:

(1) ICT manufacturing industries (manufacture of electronic components and boards, computers and peripheral equipment communication equipment and magnetic and optical media),

(2) ICT trade industries (wholesalers of computers, computer peripheral equipment, software, electronic and telecommunications equipment and parts),

(3) ICT services industries (software publishing, telecommunications, computer programming, consultancy and related activities, data processing, hosting and related activities; web portals, repair of computers and communication equipment).

Figure 1 depicts diffusion of ICTs in various Tunisian economic sectors over the period 1995-2018. We observe that the share of ICTs in total intermediate consumption varies across sectors of activity. While integration of ICTs is comparatively low (less than 5\%) in most sectors, it is relatively high in S10: Information and communication (32.62\% over the whole period), S11: Financial and insurance activities (21.31\%), S13: Professional, scientific and technical activities (18.34\%), S14: Public administration (15.38\%), and S7: Wholesale and retail trade $(11.84 \%)$.

\subsection{Model construction}

The theoretical framework used to assess the influence of ICTs and trade openness on economic growth is the model proposed by Solow (1956) and extended by Mankiw et al. (1992). The production function can be rewritten as

$$
Y_{i t}=A_{t} F\left(X_{k i t}^{\alpha_{k}}\right) \text { with } 0<\alpha_{k}<1,
$$

where $Y_{i t}$ is VA, $X_{i t}$ is a vector of the explanatory variables, $A_{t}$ is technological progress and $\alpha_{k}$ are elasticities.

This functional relationship can be specified as a Cobb-Douglas production function:

$$
Y_{i t}=A_{t} \prod_{k=1}^{K} X_{k i t}^{\alpha_{k}} \text { with } 0<\alpha_{k}<1 .
$$

We apply the natural logarithm to rewrite the linearized equation as follows: 
S1

1995-2018: 0.7\%

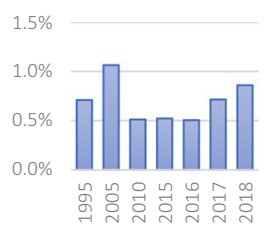

S5

1995-2018: $\mathbf{3 . 1 \%}$

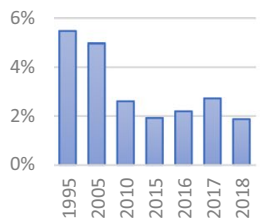

S9

1995-2018: $\mathbf{1 . 9 \%}$

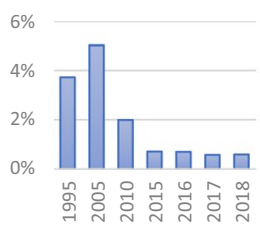

S2

$1995-2018: 5.7 \%$

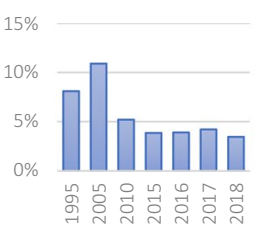

S6

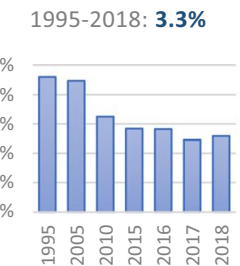

S10

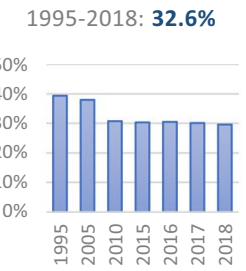

S13

1995-2018: $\mathbf{1 8 . 3 \%}$

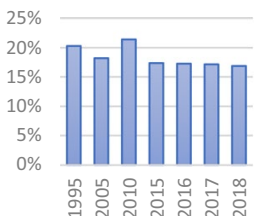

S3

S4

1995-2018: 3.0\%

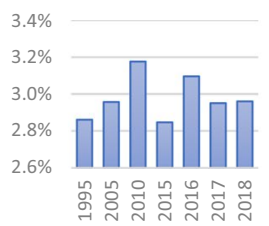

S7

1995-2018: $\mathbf{1 1 . 8 \%}$

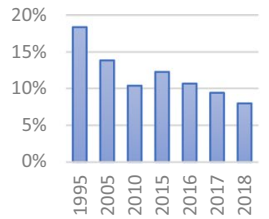

S11

1995-2018: $\mathbf{2 1 . 3 \%}$

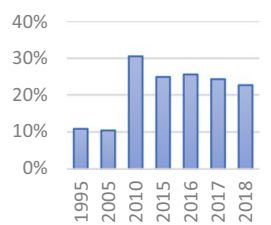

S14

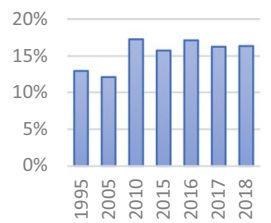

1995-2018: $4.4 \%$

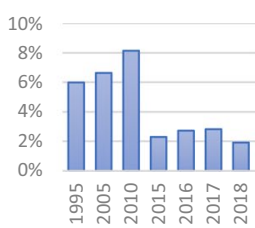

S8

1995-2018: $6.0 \%$

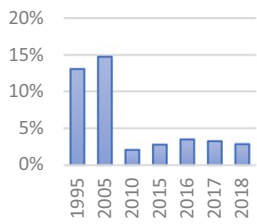

S12

1995-2018: $9.3 \%$

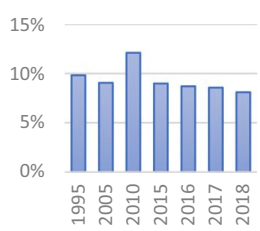

Fig. 1 Diffusion of ICTs in Tunisia's economic sectors

$$
\operatorname{Ln}\left(Y_{i t}\right)=\operatorname{Ln}\left(A_{t}\right)+\sum_{k=1}^{K} \alpha_{k} \operatorname{Ln}\left(X_{k i t}\right),
$$

where $\boldsymbol{i}$ is 14 sectors, $\boldsymbol{t}$ is the time period and $\boldsymbol{k}$ is the three explanatory variables. 


\subsection{Econometric methodology}

This study investigates the effect on economic growth (LVA) of ICTs (LIDI) and trade openness $(L T O)$ in the presence of investment $(L G F C F)$ using advanced econometric procedures. First, we test the assumption of homogeneity of the regression slopes and second check for cross-section dependence (CD) in panel. Third, we employ a panel cointegration test to check for correlation over the long term. Fourth, we use an econometric model and estimation approach based on the results of the previous tests to enable analysis of the long-run causal relationships among the variables.

\subsubsection{Test for slope homogeneity}

For the econometric estimation using panel data, we need to identify the nature of the slopes. To test the homogeneity of the slopes, we run the Pesaran and Yamagata (2008) test which is based on the dispersion of each individual weighted slope. The Monte-Carlo simulations show that the test is appropriate for small sample sizes and dynamic and unbalanced panel data.

\subsubsection{Test for cross-section dependence}

To check for potential common correlation effects among the variables, we use the CD test. Baltagi et al. (2007) warn that ignoring common correlation effects in panel data can affect the estimation results. Pesaran's (2015) CD test outperforms other tests due to its applicability to different variable lengths.

\subsubsection{Panel unit root test}

This step involves performing a test to determine the order of integration of the different variables. The existence of CD for all the variables confirmed by Pesaran's (2015) CD test implies potentially biased results by a first-generation unit root test. Given the $\mathrm{CD}$ of the errors and the slope heterogeneity, we use the second-generation panel unit root test (Pesaran's 2003 CADF, and Pesaran's 2007 CIPS). According to Baltagi et al. (2007), the CIPS test is more robust in the presence of various sources of CD including spatial or geographic proximity. Baltagi et al. (2007) examined the relative performance of several panel unit root tests in the presence of CD and found that the main attribute of this type of test is that it allows for CD, a concrete possibility overlooked in the empirical panel data literature.

\subsubsection{Panel cointegration test}

After identifying the degrees of integration of the variables, we test whether there are cointegration relationships between the non-stationary components of the data series. Cointegration tests are used widely in econometrics. The objective is to test for the existence or not of a linear combination between the stationary variables in levels and in first differences. Examining cointegration makes it possible to test for the existence 
of a long-term equilibrium relationship among the variables considered. Before 2010, cointegration was tested based on first-generation panel cointegration tests, which assume cross-sectional independence.

The first set of cointegration tests known as the first-generation panel cointegration tests includes the tests developed by Kao (1999) and Pedroni (1999, 2001, 2004) which deal with the problem of heterogeneity among different panel members. The existence of CD in the data means that the results of Pedroni and Kao's cointegration tests may not be robust.

Westerlund (2007) developed an error correction-based panel cointegration test which is robust in the presence of the CD.

The second group of cointegration tests account for possible CD in the data. In the next step, we test the long-run relationship among the variables using two panel cointegration tests by Westerlund (2007) and Pedroni (2004).

\subsubsection{Dumitrescu and Hurlin causality test}

We employ a dynamic Granger non-causality test based on the method proposed by Dumitrescu and Hurlin (2012) to check the robustness of our econometric results. While this test assumes that the coefficients differ across cross-sections, the standard Granger test assumes that all coefficients are similar for all individuals in the panel.

Dumitrescu and Hurlin's (2012) test combines cross-sectional and time series data which give it particular power. It accounts also for country heterogeneity due to economic, political, structural, or institutional particularities. The test estimates individual Granger causality for each cross-section and calculates the average of the individual tests considering a statistical significance ( $\bar{W}$ statistical) and a standardized statistic $\bar{W}$ - the $\bar{Z}$ statistic. In this case, the null hypothesis $\boldsymbol{y}$ does not homogeneously cause $\boldsymbol{x}$, and vice versa.

\subsubsection{Model specification}

In this theoretical framework, we can use a cross-section auto regressive distributed lag (CS-ARDL) modeling approach to analyze the effect of our explanatory variables on economic growth. To estimate our model, we employ the panel data procedure for the dynamic common correlated effects modeling technique developed by Chudik et al. (2016) and refined by Ditzen (2018). This approach accounts for unobservable common factors that could affect the sectors.

In our case, the lagged dependent variable is not strictly exogenous, thus Pesaran's (2006) common correlated effects (CCE) approach to estimate panel models in the presence of transverse dependence becomes inconsistent. Chudik et al. (2016) show that the estimator is more consistent if a delay is added to the cross-section means used in the estimation. Thus, Eq. (2) is rewritten as

$$
L V A_{i t}=\alpha_{0}+\sum_{j=1}^{P} \beta_{i t} L V A_{i, t-j}+\sum_{j=0}^{P} \alpha_{i t} X_{t-j}+\sum_{j=0}^{3} \phi_{i t} \bar{Z}_{t-j}+\varepsilon_{i t},
$$


Table 1 Slope homogeneity test (Pesaran and Yamagata, 2008)

\begin{tabular}{lll}
\hline Slope homogeneity tests & $\Delta$ statistic & $p$ value \\
\hline$\tilde{\Delta}$ test & $19.475^{* * *}$ & 0.000 \\
$\tilde{\Delta}_{a d j}$ test & $21.888^{* * *}$ & 0.000 \\
\hline
\end{tabular}

The null hypothesis for the slope heterogeneity test is that slope coefficients are homogenous

*** denotes significant at $1 \%$ level

\begin{tabular}{lll}
\hline Variables (in log) & CD statistic & $P$ value \\
\hline Value added (LVA) & $46.716 * * *$ & 0.000 \\
$\begin{array}{l}\text { Gross fixed capital formation per } \\
\quad \text { capita (LGFCF) }\end{array}$ & $18.012 * * *$ & 0.000 \\
ICT diffusion index (LIDI) & $45.848 * * *$ & 0.000 \\
Trade openness (LTO) & $15.565 * * *$ & 0.000 \\
\hline
\end{tabular}

The CD statistic is normally distributed under the null hypothesis of no cross-sectional dependence

$* * *$ denotes significant at $1 \%$ level

with $\bar{Z}_{t}=\left(\Delta \overline{L V A_{t}}, \bar{X}_{t}^{\prime}\right)^{\prime}$ and $X_{i t}=\left(L G F C F_{i t}, L I D I_{i t}, L T O_{i t}\right)^{\prime}$.

\section{Results and discussion}

Table 1 presents the results for the Pesaran and Yamagata (2008) test. The null hypothesis of slope homogeneity is rejected ( $p$ value $=0.000$ ). Thus, we need to consider the presence of heterogeneity in the panel data and can deduce that the model coefficients are heterogeneous and that slopes vary from country to country. This requires use of heterogeneous panel techniques.

The results of Pesaran's (2015) cross-dependence test (Table 2) confirm the existence of cross-sectional dependence for all the variables in the panel data.

This indicates the existence of a dependency factor among sectors which is evidence of the existence of a mechanism for transmitting shocks between sectors. Hence, we need to perform a second-generation unit root test.

Table 3 reports the results of the CIPS and CADF tests in levels and first differences. The assumptions of these tests require that if two or more non-stationary time series are integrated in a particular order, it is possible to estimate the cointegration regression. Therefore, the order of integration of the variables must first be determined. The results of the CIPS and CADF tests suggested that with the exception of LGFCF which is stationary in level, I(0) all the other variables are stationary in first differences I(1). We investigate the possibility of cointegration among these variables using Westerlund's (2007) and Pedroni's (2004) panel 
Table 3 Results of panel unit root

\begin{tabular}{|c|c|c|c|c|c|}
\hline \multirow[t]{2}{*}{ Variables (in log) } & \multicolumn{2}{|l|}{ Level } & \multicolumn{2}{|l|}{ First-difference } & \multirow[t]{2}{*}{ Order } \\
\hline & Without trend & With trend & Without trend & With trend & \\
\hline \multicolumn{6}{|c|}{ Cross-sectionally augmented IPS (CIPS) } \\
\hline LVA & -1.755 & -2.261 & $-4.469 * * *$ & $-4.487 * * *$ & $\mathrm{I}(1)$ \\
\hline LGFCF & $-2.727 * * *$ & -2.401 & $-4.106 * * *$ & $-4.139 * * *$ & $\mathrm{I}(0)$ \\
\hline LIDI & -1.971 & $-2.899 * *$ & $-5.242 * * *$ & $-5.203 * * *$ & $\mathrm{I}(1)$ \\
\hline LTO & $-2.296^{* *}$ & -2.494 & $-4.823 * * *$ & $-4.888 * * *$ & $\mathrm{I}(1)$ \\
\hline \multicolumn{6}{|c|}{ Cross-sectionally augmented Dicky-Fuller (CADF) } \\
\hline LVA & -1.733 & -1.799 & $-2.171^{*}$ & -2.148 & $\mathrm{I}(1)$ \\
\hline LGFCF & $-2.162 *$ & -2.270 & $-2.374 * *$ & -2.313 & $\mathrm{I}(0)$ \\
\hline LIDI & -1.267 & -2.557 & $-2.879 * * *$ & $-2.873 * *$ & $\mathrm{I}(1)$ \\
\hline LTO & -1.525 & -1.728 & $-2.362^{* *}$ & -2.450 & $\mathrm{I}(1)$ \\
\hline
\end{tabular}

The panel unit root test was performed under the null hypothesis that the variables are homogeneous and non-stationary

$* * *, * *$, and $*$ denote statistical significance level at $1 \%, 5 \%$, and $10 \%$, respectively

Table 4 Westerlund (2007) panel cointegration tests

\begin{tabular}{llll}
\hline Statistic & Value & $Z$-value & $P$ value \\
\hline $\mathrm{Gt}$ & $-3.768^{* * * *}$ & 7.521 & 0.000 \\
$\mathrm{Ga}$ & $-11.554 * *$ & 2.242 & 0.013 \\
$\mathrm{Pt}$ & $-14.446^{* * *}$ & 7.263 & 0.000 \\
$\mathrm{~Pa}$ & $-11.051^{* * *}$ & 4.018 & 0.000 \\
\hline
\end{tabular}

The Gt and Ga statistics test cointegration for each cross-section, and $\mathrm{Pt}$ and $\mathrm{Pa}$ test cointegration in the panel under the null hypothesis of no cointegration

$* * *$ and $* *$ denote statistical significance level at $1 \%$ and $5 \%$, respectively

cointegration tests which allow us to determine the existence in the long run of a correlation between several time series.

Table 4 presents the results for all the variables of the Westerlund (2007) cointegration test using data for 14 sectors. This method has the advantage of testing cointegration in the presence of heterogeneous slope coefficients and dependence among individual data in the panel. The null hypothesis is that there is no longterm cointegration among the variables; the alternative hypothesis assumes the opposite.

The results of the Westerlund (2007) test reject the hypothesis of non-cointegration at the panel rather than at the individual level. The results of the Pedroni (2004) test (Table 5) indicate that the null hypothesis of no cointegration is 
Table 5 Pedroni (2004) panel cointegration test

Table 6 CS-ARDL panel data estimation results

\begin{tabular}{llllll}
\hline Tests & \multicolumn{2}{l}{ Within-dimension } & & \multicolumn{2}{l}{ Between-dimension } \\
\cline { 2 - 3 } \cline { 6 - 6 } \cline { 5 - 6 } & Statistic & $P$ values & & Statistic & $P$ value \\
\hline$\nu$-statistic & -0.3352 & 0.368 & & \\
$\rho$-statistic & $-3.716^{* * *}$ & 0.000 & & $-2.383^{* * * *}$ & 0.008 \\
PP-statistic & $-8.202^{* * *}$ & 0.000 & & $-9.006^{* * * *}$ & 0.000 \\
ADF-statistic & $-7.973^{* * *}$ & 0.000 & & $-8.516^{* * * *}$ & 0.000 \\
\hline
\end{tabular}

All test statistics are normally distributed under a null hypothesis of no cointegration

*** denotes significant at $1 \%$ level

\begin{tabular}{|c|c|c|c|c|}
\hline & \multicolumn{2}{|l|}{$\begin{array}{l}\text { Model } 1 \\
\text { (All sectors) }\end{array}$} & \multicolumn{2}{|c|}{$\begin{array}{l}\text { Model } 2 \\
\text { (Less ICT-intensive } \\
\text { sectors) }\end{array}$} \\
\hline & Coefficient & $P$ value & Coefficient & $P$ value \\
\hline \multicolumn{5}{|c|}{ Short-run results } \\
\hline ECT & $\begin{array}{l}-0.768 * * * \\
(0.1084)\end{array}$ & 0.000 & $\begin{array}{l}-0.696 * * * \\
(0.1451)\end{array}$ & 0.000 \\
\hline LGFCF & $\begin{array}{l}0.110 * * \\
(0.0430)\end{array}$ & 0.011 & $\begin{array}{l}0.135 * \\
(0.0744)\end{array}$ & 0.069 \\
\hline$\Delta$ LIDI & $\begin{array}{l}0.130 * * \\
(0.0538)\end{array}$ & 0.016 & $\begin{array}{l}0.082 * * \\
(0.0326)\end{array}$ & 0.012 \\
\hline$\Delta \mathrm{LTO}$ & $\begin{array}{l}0.148 * * * \\
(0.0486)\end{array}$ & 0.002 & $\begin{array}{l}0.167 * \\
(0.0950)\end{array}$ & 0.079 \\
\hline \multicolumn{5}{|c|}{ Long-run results } \\
\hline LGFCF & $\begin{array}{l}0.063 * * * \\
(0.0216)\end{array}$ & 0.004 & $\begin{array}{l}0.068 * * \\
(0.0322)\end{array}$ & 0.034 \\
\hline LIDI & $\begin{array}{l}0.079 * * \\
(0.0312)\end{array}$ & 0.011 & $\begin{array}{l}0.049 * * * \\
(0.0184)\end{array}$ & 0.008 \\
\hline LTO & $\begin{array}{l}0.100 * * * \\
(0.0332)\end{array}$ & 0.003 & $\begin{array}{l}0.085 \\
(0.0515)\end{array}$ & 0.100 \\
\hline CD statistic & -0.51 & 0.608 & -0.54 & 0.586 \\
\hline Root MSE & 0.05 & & 0.06 & \\
\hline
\end{tabular}

The CD statistic test is standard normally distributed under the null of hypothesis of weak cross-sectional dependence. Coefficients are reported with standard errors in brackets

$* * *, * *$, and $*$ denote statistical significance level at $1 \%, 5 \%$, and $10 \%$, respectively

rejected for six of the seven statistics. We therefore need to estimate the longterm equilibrium relationships among the variables. 
The CS-ARDL model results for the short-term (top rows) and long-term (bottom rows) relationship are presented in Table 6. Note that the short-term results of the CS-ARDL model are similar in magnitude and sign to the long-term results.

We note also that the CD test ( $p$ value 0.586 ) does not reject the null hypothesis of weak cross-section dependence, suggesting that the estimation results are not biased by the presence of cross-section dependence.

The results show that as expected, the coefficient of the error correction term (ECT) is negative and significant $(-0.768, p=0.000)$. Thus, the ECT provides no evidence rejecting cointegration. Similarly, the long-run results based on the CSARDL estimator suggest that VA is positively and significantly related to GFCF, trade openness and ICT. A $1 \%$ increase in LGFCF, LTO and LIDI, increases LVA by $0.11 \%, 0.15 \%$ and $0.13 \%$, respectively.

LIDI is significant at the $5 \%$ level, indicating that availability and diffusion of ICTs can enhance VA growth through multiple transmission channels.

First, firms use the outputs of the ICT sector either as capital goods (embodied technical progress) or as intermediate consumption goods which is supposed to foster growth of VA. Households also demand ICT products as final consumption goods which stimulates growth. The main mechanism assumed here is related to the existence of a Keynesian ICT investment multiplier which is larger than the non-ICT investment multiplier. Thus, investment regains fundamental importance not directly as a factor of growth but indirectly as a vector of technical progress.

Second, the downward slide in ICT prices has a deflator effect on the rest of the economy. For example, the continuing sharp reductions in hardware and software prices, have led firms to intensify their ICT investments. Productivity gains in the ICT sector act as a technology deflator on the rest of the economy, controlling inflation and/or increasing real income and growth.

Third, the relative increase in the share of capital over labor in the use of inputs when ICT is considered as a biased technology. In this case, capital substitutes for labor, and skilled labor displaces unskilled labor in the investment process. This generates an increase in capital intensity and productivity and allows for changes in the organization of production, markets and firms, a rethinking of business practices, simplification of the supply chain and a reduced transaction costs.

Fourth, by increasing the informational content of goods and services, ICTs increase the quality and differentiation of products and services. These benefits improve the utility of consumers without changing the price or quantity of the products that incorporate ICTs.

Fifth, the externalities and spillover effects among sectors associated with ICTs are widely diffused throughout the economy and increase production efficiency and rates of technical progress.

Tables 7 and 8 show that overall, our sectoral study reveals important heterogeneity in the impacts on economic growth across sectors of the variables studied. Heterogeneity across sectors has been shown to be an important characteristic of the Tunisian economy.

While trade openness appears to have a positive and statistically significant effect on economic growth over the long term, the results at sectoral level are mixed with seemingly only a few sectors benefitting. However, this weak impact 
Table 7 Results of long-term estimates at the sector level

\begin{tabular}{|c|c|c|c|}
\hline Sector & LGFCF & LIDI & LTO \\
\hline S1: Agriculture, forestry and fishing & $\begin{array}{l}0.003 \\
(0.0226)\end{array}$ & $\begin{array}{l}0.030 \\
(0.0267)\end{array}$ & $\begin{array}{l}0.254^{*} \\
(0.1540)\end{array}$ \\
\hline S2: Mining and quarrying & $\begin{array}{l}0.106 * * \\
(0.0487)\end{array}$ & $\begin{array}{l}-0.100 \\
(0.0856)\end{array}$ & $\begin{array}{l}0.232 * * * \\
(0.0837)\end{array}$ \\
\hline S3: Manufacturing & $\begin{array}{l}0.021 * * \\
(0.0089)\end{array}$ & $\begin{array}{l}0.092 \\
(0.0594)\end{array}$ & $\begin{array}{l}0.092 * \\
(0.0531)\end{array}$ \\
\hline S4: Electricity, gas, steam and air conditioning supply & $\begin{array}{l}0.131 * * * \\
(0.0235)\end{array}$ & $\begin{array}{l}0.189 * \\
(0.1006)\end{array}$ & $\begin{array}{l}-0.055 \\
(0.2646)\end{array}$ \\
\hline $\begin{array}{l}\text { S5: Water supply; sewerage, waste management and } \\
\text { remediation activities }\end{array}$ & $\begin{array}{l}0.220 * * * \\
(0.0411)\end{array}$ & $\begin{array}{l}-0.060 \\
(0.0761)\end{array}$ & $\begin{array}{l}-0.021 \\
(0.0449)\end{array}$ \\
\hline S6: Construction & $\begin{array}{l}0.248 * * \\
(0.1209)\end{array}$ & $\begin{array}{l}-0.062 \\
(0.2856)\end{array}$ & $\begin{array}{l}0.077 \\
(0.1628)\end{array}$ \\
\hline S7: Wholesale and retail trade & $\begin{array}{l}0.603 * * * \\
(0.1710)\end{array}$ & $\begin{array}{l}0.492 * * * \\
(0.1537)\end{array}$ & $\begin{array}{l}-0.168^{* * * *} \\
(0.0421)\end{array}$ \\
\hline S8: Transportation and storage & $\begin{array}{l}0.160 * * * \\
(0.0422)\end{array}$ & $\begin{array}{l}0.004 \\
(0.1103)\end{array}$ & $\begin{array}{l}-0.090 \\
(0.1185)\end{array}$ \\
\hline S9: Accommodation and food service activities & $\begin{array}{l}0.270 * * * \\
(0.0982)\end{array}$ & $\begin{array}{l}0.144 * \\
(0.0806)\end{array}$ & $\begin{array}{l}-0.036 \\
(0.0423)\end{array}$ \\
\hline S10: Information and communication & $\begin{array}{l}0.332 * * * \\
(0.1098)\end{array}$ & $\begin{array}{l}1.005 * * * \\
(0.1341)\end{array}$ & $\begin{array}{l}0.345 * * * \\
(0.0831)\end{array}$ \\
\hline S11: Financial and insurance activities & $\begin{array}{l}0.517 * \\
(0.2898)\end{array}$ & $\begin{array}{l}0.314^{*} \\
(0.1697)\end{array}$ & $\begin{array}{l}-0.028 \\
(0.0301)\end{array}$ \\
\hline S12: Real estate activities & $\begin{array}{l}-0.027 \\
(0.0873)\end{array}$ & $\begin{array}{l}0.002 \\
(0.0435)\end{array}$ & $\begin{array}{l}-0.009 \\
(0.0526)\end{array}$ \\
\hline S13: Professional, scientific and technical activities & $\begin{array}{l}0.102 * \\
(0.0594)\end{array}$ & $\begin{array}{l}0.061 * \\
(0.0329)\end{array}$ & $\begin{array}{l}0.368 \\
(0.2262)\end{array}$ \\
\hline S14: Public administration & $\begin{array}{l}0.008 \\
(0.0659)\end{array}$ & $\begin{array}{l}0.092 * \\
(0.0506)\end{array}$ & $\begin{array}{l}-0.040 \\
(0.0726)\end{array}$ \\
\hline
\end{tabular}

Coefficients are reported with standard errors in brackets

$* * *, * *$, and $*$ denote statistical significance level at $1 \%, 5 \%$, and $10 \%$, respectively

can be reversed by structural reforms aimed at improving access to investment, human capital, innovation capabilities, and competitiveness and diversifying the economy.

In terms of the effect of the diffusion of ICTs and digitalization of the economy on sectoral performance, it should be noted that all sectors of the economy including traditional sectors which would be less likely to be affected, will be impacted by the changes promoted by the introduction of digital technologies. The digital transformation will affect all sectors to varying degrees. Some such as tourism and trade are heavily influenced by digitization. Traditional players in these sectors have had to redesign their business models: for example, tour operators have been forced to reconsider the scope and operation of their physical agency networks, while airlines have increased direct distribution which relies on use of the internet. On the other hand, some sectors are only beginning this 
Table 8 Long-run elasticity of value added with regard to ICT: industry level

\begin{tabular}{|c|c|c|c|}
\hline \multirow[b]{2}{*}{ Sector } & \multicolumn{3}{|c|}{ ICT diffusion index (LIDI) } \\
\hline & $1995-2018$ & 1995-2009 & $2004-2018$ \\
\hline S1: Agriculture, forestry and fishing & $\begin{array}{l}0.030 \\
(0.0267)\end{array}$ & $\begin{array}{l}0.051 \\
(0.0910)\end{array}$ & $\begin{array}{l}0.040 \\
(0.0265)\end{array}$ \\
\hline S2: Mining and quarrying & $\begin{array}{l}-0.100 \\
(0.0856)\end{array}$ & $\begin{array}{l}-0.184 \\
(0.2439)\end{array}$ & $\begin{array}{l}-0.450 \\
(0.5712)\end{array}$ \\
\hline S3: Manufacturing & $\begin{array}{l}0.092 \\
(0.0594)\end{array}$ & $\begin{array}{l}0.053 \\
(0.0267)\end{array}$ & $\begin{array}{l}0.107 \\
(0.0756)\end{array}$ \\
\hline S4: Electricity, gas, steam and air conditioning supply & $\begin{array}{l}0.189 * \\
(0.1006)\end{array}$ & $\begin{array}{l}0.915 * * * \\
(0.1809)\end{array}$ & $\begin{array}{l}0.366^{* * * *} \\
(0.1158)\end{array}$ \\
\hline $\begin{array}{l}\text { S5: Water supply; sewerage, waste management and } \\
\text { remediation activities }\end{array}$ & $\begin{array}{l}-0.060 \\
(0.0761)\end{array}$ & $\begin{array}{l}0.131 \\
(0.1928)\end{array}$ & $\begin{array}{l}-0.024 \\
(0.0809)\end{array}$ \\
\hline S6: Construction & $\begin{array}{l}-0.062 \\
(0.2856)\end{array}$ & $\begin{array}{l}-0.331 \\
(0.2526)\end{array}$ & $\begin{array}{l}0.016 \\
(0.4045)\end{array}$ \\
\hline S7: Wholesale and retail trade & $\begin{array}{l}0.492 * * * \\
(0.1537)\end{array}$ & $\begin{array}{l}-0.459 \\
(0.3592)\end{array}$ & $\begin{array}{l}0.847 * * * \\
(0.1446)\end{array}$ \\
\hline S8: Transportation and storage & $\begin{array}{l}0.004 \\
(0.1103)\end{array}$ & $\begin{array}{l}0.249 * * \\
(0.1078)\end{array}$ & $\begin{array}{l}-0.059 \\
(0.1787)\end{array}$ \\
\hline S9: Accommodation and food service activities & $\begin{array}{l}0.144^{*} \\
(0.0806)\end{array}$ & $\begin{array}{l}0.229 * \\
(0.1192)\end{array}$ & $\begin{array}{l}0.031 \\
(0.0627)\end{array}$ \\
\hline S10: Information and communication & $\begin{array}{l}1.005^{* * * *} \\
(0.1341)\end{array}$ & $\begin{array}{l}1.401 * * \\
(0.6334)\end{array}$ & $\begin{array}{l}0.926^{* * * *} \\
(0.3213)\end{array}$ \\
\hline S11: Financial and insurance activities & $\begin{array}{l}0.314^{*} \\
(0.1697)\end{array}$ & $\begin{array}{l}0.078 \\
(0.1415)\end{array}$ & $\begin{array}{l}0.242 * * * \\
(0.0677)\end{array}$ \\
\hline S12: Real estate activities & $\begin{array}{l}0.002 \\
(0.0435)\end{array}$ & $\begin{array}{l}-0.117 \\
(0.1811)\end{array}$ & $\begin{array}{l}0.305 \\
(0.2214)\end{array}$ \\
\hline S13: Professional, scientific and technical activities & $\begin{array}{l}0.061 * \\
(0.0329)\end{array}$ & $\begin{array}{l}0.059 * * \\
(0.0267)\end{array}$ & $\begin{array}{l}-0.073 \\
(0.0465)\end{array}$ \\
\hline S14: Public administration & $\begin{array}{l}0.092^{*} \\
(0.0506)\end{array}$ & $\begin{array}{l}0.141 * * \\
(0.0668)\end{array}$ & $\begin{array}{l}0.097 \\
(0.0690)\end{array}$ \\
\hline
\end{tabular}

$* * *, * *$, and $*$ denote statistical significance level at $1 \%, 5 \%$, and $10 \%$, respectively

transformation. For example, only the most pioneering construction sector firms are testing and adopting digital construction technologies.

Some of the leading economic sectors are heavily involved in the digital transformation. Financial and insurance activities, professional, scientific and technical activities, transportation and storage and public administration are among the sectors most affected by the digital transformation in Tunisia. While some sectors are benefiting immediately, others face several obstacles in the move to this new paradigm. This applies particularly to agriculture, construction and manufacturing. Although the agriculture sector could benefit greatly from digitization, it is slow to adopt new technologies. In most cases, in Tunisia agriculture continues to use traditional practices. The construction sector also is lagging behind some other sectors. This delay in digitization of the construction sector is resulting in both lower productivity and profitability, and is likely to fail to meet Tunisia's future construction 
needs to satisfy demand from an increased urban population. Tunisia suffers from water shortages and the deployment of water saving or water use efficiency technologies is essential. Some incentives have been provided in this area but much more needs to be done to invest in Water 4.0.

\subsection{Robustness}

To analyze model uncertainty and test whether the estimated effects are sensitive to changes in the model specification, we check the robustness of the CS-ARDL model results (Table 6). First, we estimate model 1 which includes all sectors. Second, we estimate model 2 which excludes the most ICT-intensive sectors and compare the changes in the coefficient and statistical significance of each variable in model 2. Third, we employ the Dumitrescu and Hurlin (2012) causality test to check for a causal relationship among the variables.

The results of the Dumitrescu and Hurlin (2012) panel Granger causality test for the CS-ARDL model are presented in Table 9. We observe four bidirectional causal relationships between VA $\leftrightarrow \mathrm{GFCF}, \mathrm{VA} \leftrightarrow \mathrm{ICT}$ Index, VA $\leftrightarrow$ Trade, and ICT Index $\leftrightarrow$ Trade, and evidence of two unidirectional causal relationships: $\mathrm{GFCF} \rightarrow$ Trade, and ICT Index $\rightarrow$ GFCF.

The estimation results for models 1 and 2 and the results of the causality test are consistent, suggesting that the models are robust and do not suffer from mis-specification.

\section{Conclusion and policy implications}

We set out to investigate the dynamic relationship between ICT diffusion, trade openness and economic growth drawing on the work by Huchet-Bourdon et al. (2018), Carnevali et al. (2020), Toader et al. (2018), Zaman et al. (2021), Mickoleit et al. (2009), Antonelli (2017), Fukuda (2020), Toader et al. (2018), Frank et al. (2019); Park (2018), Vu et al. (2020), Taalbi (2019), Czernich et al. (2011), and Fernandez-Portillo et al. (2020) who consider trade openness and ICT diffusion relevant

Table 9 Dumitrescu and Hurlin (2012) Granger non-causality tests

\begin{tabular}{lllll}
\hline & Value added & GFCF & ICT Index & Trade openness \\
\hline Value added & & $18.2796^{* * *}$ & $3.8614^{* * * *}$ & $4.2455^{* * *}$ \\
& & 13.2635 & 7.5707 & 8.5868 \\
GFCF & $2.8524^{* * *}$ & & 1.5188 & $1.6522^{*}$ \\
& 4.9009 & & 1.3725 & 1.7256 \\
ICT Index & $1.7841^{* *}$ & $63.8949^{* * *}$ & & $6.9847^{* * *}$ \\
& 2.0745 & 62.5336 & & 15.8341 \\
Trade openness & $3.5396^{* * *}$ & 1.5751 & $2.0608^{* * *}$ & \\
& 6.7191 & 1.5217 & 2.8066 & \\
\hline
\end{tabular}

The W-statistics marked with (***) are statistically significant at $1 \%$ level. Z-statistics are shown in parentheses 
factors to foster economic activity, create jobs and improve the quality of products and services. To capture the economic importance of ICT, we considered the role of ICT sector outputs in the VA of each sector. We obtained three main findings which have some policy implications.

First, we found a positive impact of ICTs on economic growth. In addition, the results show a bidirectional causal relationship between ICT and VA which suggests that the Tunisian economy should focus more on manufacturing of ICT products to sustain economic growth. Tunisia should strengthen its digital infrastructure and deploy new technologies. Tunisian enterprises should prioritize implementation of new organizational practices to enable adoption of new digital technologies. The workforce must be trained in the digital skills that will be required for tomorrow's jobs. Bridging the digital divide should be a priority; digital inclusion drives economic development and growth.

Second, value added is positively and significantly related to trade openness in the long run. The sectoral level results are mixed with only a few sectors appearing to benefit. However, this weak impact could be reversed by continuing structural reforms to improve access to investment, human capital, innovation capacity, competitiveness and economic diversification. In addition to contributing directly to output growth, ICT generates natural advantages and openness effects (ICT has a causal effect on trade openness). In the case of significant effects, this would translate into accelerated multifactor productivity growth.

Third, the results suggest that VA is related positively to GFCF. ICT has a positive impact on investment. ICT allows the creation of new capital goods, significantly improved existing products and development of new services.

With the exception of a few sectors, investment in ICT does not have a significant effect on productivity at sectoral level. This can be explained by lack of investment and organizational change required to adopt new technologies in some sectors. In addition, on its own technology cannot solve development problems; technology only provides opportunities.

In summary, Tunisia has taken some important steps towards becoming a knowledge economy but needs to overcome numerous economic, social, political, cultural and education obstacles. To benefit from the opportunities enabled by an information economy, Tunisia must prioritize investment in $R \& D$, and science and technology and implement projects to encourage innovation and spillover effects among economic sectors. To reap the benefits from trade openness and increase international trade involving domestic enterprises, and to overcome traditional institutional and legal barriers will require adjustments to legal framework to enable easy and secure information exchange.

\section{References}

Adeleye N, Eboagu C (2019) Evaluation of ICT development and economic growth in Africa. NETNOMICS 20: 31-53. https://doi.org/10.1007/s11066-019-09131-6

Antonelli C (2017) Digital knowledge generation and the appropriability trade-off. Telecommun Policy 41(10):991-1002. https://doi.org/10.1016/j.telpol.2016.12.002 
Baltagi BH, Bresson G, Pirotte A (2007) Panel unit root tests and spatial dependence. J Appl Economet 22:339-360. https://doi.org/10.1002/jae.950

Ben Lahouel B, Taleb L, Ben Zaied Y, Managi S (2021) Does ICT change the relationship between total factor productivity and $\mathrm{CO} 2$ emissions? Evidence based on a nonlinear model. Energy Econ 101:105406. https://doi.org/10.1016/j.eneco.2021.105406

Bertschek I, Cerquera D, Klein GJ (2013) More bits - more bucks? Measuring the impact of broadband internet on firm performance. Inf Econ Policy 25:190-203. https://doi.org/10.1016/j.infoecopol. 2012.11.002

Bresnahan T, Trajtenberg M (1995) General purpose technologies 'Engines of growth'? J Econometrics 65(1):83-108. https://doi.org/10.1016/0304-4076(94)01598-T

Carnevali E, Godin A, Lucarelli S, Veronese Passarella M (2020) Productivity growth, Smith effects and Ricardo effects in Euro Area's manufacturing industries. Metroeconomica 71:129-155. https://doi. org/10.1111/meca. 12270

Chudik A, Mohaddes K, Pesaran MH, Raissi M (2016) Long-run effects in large heterogeneous panel data models with crosssectionally correlated errors. In: G. González-Rivera, R. C. Hill, \& T.-H. Lee (Eds.), Advances in Econometrics: Vol. 36-Essays in Honor of Aman Ullah (pp. 85-135). Emerald.

Czernich N, Falck O, Kretschmer T, Woessmann L (2011) Broadband infrastructure and economic growth. Econ J (london) 121(552):505-532. https://doi.org/10.1111/j.1468-0297.2011.02420.x

Ditzen J (2018) Estimating dynamic common correlated effects in stata. Stand Genomic Sci 18(3):585617. https://doi.org/10.1177/1536867X1801800306

Dumitrescu E-I, Hurlin C (2012) Testing for Granger non-causality in heterogeneous panels. Econ Model 29:1450-1460. https://doi.org/10.1016/j.econmod.2012.02.014

Ejemeyovwi JO, Osabuohien ES (2020) Investigating the Relevance of mobile technology adoption on inclusive growth in West Africa. Contemporary Social Science 15(1):48-61. https://doi.org/10. 1080/21582041.2018.1503320

Fernandez-Portillo A, Almodovar-Gonzalez M, Hernandez-Mogollon R (2020) Impact of ICT development on economic growth. A study of OECD European union countries. Technol Soc 63:101420. https://doi.org/10.1016/j.techsoc.2020.101420

Frank AG, Mendes GHS, Ayala NF, Ghezzi A (2019) Servitization and Industry 4.0 convergence in the digital transformation of product firms: a business model innovation perspective. Technol Forecasting Social Change 141(C): 341-351. https://doi.org/10.1016/j.techfore.2019.01.014

Fukuda K (2020) Science, technology and innovation ecosystem transformation toward society 5.0 Int J Prod Econ 220: 107460. https://doi.org/10.1016/j.ijpe.2019.07.033

Haftu GG (2019) Information communications technology and economic growth in Sub-Saharan Africa: A PANEL DATA APPROACH. Telecommun Policy 43(1):88-99. https://doi.org/10.1016/j.telpol. 2018.03.010

Haller SA, Lyons S (2015) Broadband adoption and firm productivity: Evidence from Irish manufacturing firms. Telecommun Policy 39:1-13. https://doi.org/10.1016/j.telpol.2014.10.003

Hamel Breghish S, Neama Ali S (2021) Analyzing and measuring the impact of trade openness on the gross domestic product growth of the Iraqi economy after 2003. Materials Today: Proceedings. Advance online publication. https://doi.org/10.1016/j.matpr.2021.04.130

Huchet-Bourdon M, Le Mouël C, Vijil M (2018) The relationship between trade openness and economic growth: Some new insights on the openness measurement issue. World Economy 41(1):59-76. https://doi.org/10.1111/twec. 12586

Idris J, Yusop Z, Habibullah MS (2017) Trade openness and economic growth: A causality test in panel perspective. Int J Business Soc 17(2). https://doi.org/10.33736/ijbs.525.2016

Ishida $H$ (2015) The effect of ICT development on economic growth and energy consumption in Japan. Telematics Inform 32(1):79-88. https://doi.org/10.1016/j.tele.2014.04.003

Jorgenson DW, Vu KM (2016) The ICT revolution, world economic growth, and policy issues. Telecommun Policy 40(5):383-397. https://doi.org/10.1016/j.telpol.2016.01.002

Jung J, Lopez-Bazo E (2020) On the regional impact of broadband on productivity: the case of Brazil. Telecommunications Policy 44(1):101826. https://doi.org/10.1016/j.telpol.2019.05.002

Kallal R, Haddaji A, Ftiti Z (2021) ICT diffusion and economic growth: evidence from the sectorial analysis of a periphery country. Technol Forecast Soc Chang 162:120403. https://doi.org/10.1016/j.techf ore. 2020.120403

Kao C (1999) Spurious regression and residual-based tests for cointegration in panel data. J Econ 90(1):1-44. https://doi.org/10.1016/S0304-4076(98)00023-2 
Leontief, W. (1986). Technological change, prices, wages, and rates of return on capital in the U.S. economy. First published as Chapter 19 in W. Leontief, Input-output economics. Second edition. New York: Oxford University Press, 392-417.

Mankiw NG, Romer D, Weil D (1992) A contribution to the empirics of economic growth. Q J Econ 107(2):407-437. https://doi.org/10.2307/2118477

Mayer W, Madden G, Wu C (2020) Broadband and economic growth: a reassessment. Inf Technol Dev 26(1):128-145. https://doi.org/10.1080/02681102.2019.1586631

Mickoleit A, Reimsbach-Kounatze C, Serra-Vallejo C, Vickery G, Wunsch-Vincent S (2009) The impact of the crisis on icts and their role in the recovery, No 163. OECD Publishing, OECD Digital Economy Papers

Miller RE, Blair PD (2009) Input-output analysis: foundations and extensions. Cambridge University Press. https://doi.org/10.1017/CBO9780511626982

Musila JW, Yiheyis Z (2015) The impact of trade openness on growth: the case of Kenya. J Policy Modeling 37(2):342-354. https://doi.org/10.1016/j.jpolmod.2014.12.001

Mustafin A, Kantarbayeva A (2018) Opening the Leontief's Black Box. Heliyon 4(5):e00626. https://doi. org/10.1016/j.heliyon.2018.e00626

Naanaa ID, Sellaouti F (2017) Technological diffusion and growth: case of the Tunisian manufacturing sector. J Knowl Econ 8:369-383. https://doi.org/10.1007/s13132-015-0270-7

Niebel T (2018) ICT and economic growth-comparing developing, emerging and developed countries. World Dev 104:197-211. https://doi.org/10.1016/j.worlddev.2017.11.024

Njoh AJ (2018) The relationship between modern information and communications technologies (ICTs) and development in Africa. Util Pol 50:83-90. https://doi.org/10.1016/j.jup.2017.10.005

OECD (2009) Towards green ICT strategies-assessing policies and programmes on ICT and the environment. OECD, Working Party on the Information Economy

Park SC (2018) The fourth industrial revolution and implications for innovative cluster policies. AI \& Soc 33:433-445. https://doi.org/10.1007/s00146-017-0777-5

Pedroni P (1999) Critical values for cointegration tests in heterogeneous panels with multiple regressors. Oxford Bull Econ Stat 61(S1):653-670. https://doi.org/10.1111/1468-0084.61.s1.14

Pedroni P (2001) Purchasing power parity tests in cointegrated panels. Rev Econ Stat 83(4):727-731. https://doi.org/10.1162/003465301753237803

Pedroni P (2004) Panel cointegration: asymptotic and finite sample properties of pooled time series tests with an application to the PPP hypothesis. Economet Theor 20(3):597-625. https://doi.org/10.1017/ S0266466604203073

Pesaran MH (2006) Estimation and inference in large heterogeneous panels with a multifactor error structure. Econometrica 74(4):967-1012. https://doi.org/10.1111/j.1468-0262.2006.00692.x

Pesaran MH (2007) A simple panel unit root test in the presence of cross section dependence. J Appl Economet 22(2):265-312. https://doi.org/10.1002/jae.951

Pesaran MH (2015) Testing weak cross-sectional dependence in large panels. Economet Rev 34(610):1089-1117. https://doi.org/10.1080/07474938.2014.956623

Pesaran MH, Yamagata T (2008) Testing slope homogeneity in large panels. J Econometrics 142(1):5093. https://doi.org/10.1016/j.jeconom.2007.05.010

Pesaran MH (2003) A simple panel unit root test in the presence of cross section dependence. Cambridge Working Papers in Economics 0346. https://doi.org/10.2139/ssrn.457280

Saidi K, Hassen LB, Hammami MS (2015) Econometric analysis of the relationship between ICT and economic growth in Tunisia. J Knowl Econ 6(4):1191-1206. https://doi.org/10.1007/ s13132-014-0204-9

Samimi AJ, Arab M (2011) Information and communication technology (ICT) and total factor productivity (TFP): evidence from selected countries of the world. Middle East J Sci Res 10(6):768-776

Sassi S, Goaied M (2013) Financial development, ICT diffusion and economic growth: Lessons from MENA region. Telecommunications Policy 37(4-5):252-261. https://doi.org/10.1016/j.telpol.2012. 12.004

Schumpeter, J. A. (1942). Capitalism, Socialism and Democracy (Vol. 36). Harper \& Row.

Solow RM (1956) A contribution to the theory of economic growth. Q J Econ 70(1):65-94. https://doi. org/10.2307/1884513

Suh Y, Lee H (2017) Developing ecological index for identifying roles of ICT industries in mobile ecosystems: the inter-industry analysis approach. Telematics Inform 34(1):425-437. https://doi.org/10. 1016/j.tele.2016.06.007 
Taalbi J (2019) Origins and pathways of innovation in the third industrial revolution. Ind Corp Chang 28(5):1125-1148

Thompson HG Jr, Garbacz C (2011) Economic impacts of mobile versus fixed broadband. Telecommun Policy 35:999-1009. https://doi.org/10.1016/j.telpol.2011.07.004

Toader E, Firtescu BN, Roman A, Anton SG (2018) Impact of information and communication technology infrastructure on economic growth: an empirical assessment for the EU countries. Sustainability (basel) 10(10):3750. https://doi.org/10.3390/su10103750

Trejos S, Barboza G (2015) Dynamic estimation of the relationship between trade openness and output growth in Asia. J Asian Econ 36:110-125. https://doi.org/10.1016/j.asieco.2014.10.001

United Nations (2008). International Standard Industrial Classification of All Economic Activities Revision 4", Series M: Miscellaneous Statistical Papers, No. 4 Rev. 4, ST/ESA/STAT/SER.M/4/REV.4.

Vu K (2011) Sources of Singapore's economic growth, 1965-2008: Trends, patterns and policy implications. ASEAN Econ Bull 28(3):315-336. https://doi.org/10.1355/ae28-3c

Vu K, Hanafizadeh P, Bohlin E (2020) ICT as a driver of economic growth: A survey of the literature and directions for future research. Telecommun Policy 44(2):101922. https://doi.org/10.1016/j.telpol. 2020.101922

Westerlund J (2007) Testing for error correction in panel data. Oxford Bull Econ Stat 69:709-748. https:// doi.org/10.1111/j.1468-0084.2007.00477.x

Zaman M, Pinglu C, Hussain SI, Ullah A, Qian N (2021) Does regional integration matter for sustainable economic growth? Fostering the role of FDI, trade openness, IT exports, and capital formation in BRI countries. Heliyon 7(12):e08559. https://doi.org/10.1016/j.heliyon.2021.e08559

Publisher's Note Springer Nature remains neutral with regard to jurisdictional claims in published maps and institutional affiliations. 